\title{
The Impact of Turnover Ratios on Jordanian Services Sectors’ Performance
}

\author{
Lina Warrad \\ Applied Science University, Amman, Jordan \\ Rania Al Omari \\ Al-Asra University, Amman, Jordan
}

\begin{abstract}
Profitability ratios are a group of financial ratios that indicate how much profit a business is earning within a certain context, while asset utilization ratios indicate how efficient a business is in operating its assets to generate cash. The difference between profitability ratios and turnover ratios is the fact that turnovers are more specific. While profitability ratios measure overall performance in terms of profits, asset utilization ratios focus on specific measurements within the business. ${ }^{1}$ We conduct this study to verify the impact of turnover ratios on Jordanian services sectors' performance during the period from 2009 to 2012. The study showed that there is no significant impact of turnover ratios on Jordanian services sectors' profitability, and by testing the main and sub hypotheses, the study revealed that there is no significant impact of turnover ratios on Jordanian services sectors' return on assets (ROA), there is no significant impact of working capital turnover on Jordanian services sectors' ROA, there is no significant impact of total asset turnover on Jordanian services sectors' ROA, and there is no significant impact of fixed asset turnover on Jordanian services sectors' ROA. Also, the study showed that there is no significant impact of turnover ratios on Jordanian services sectors' return on equity (ROE), there is no significant impact of working capital turnover on Jordanian services sectors' ROE, there is no significant impact of total asset turnover on Jordanian services sectors' ROE, and there is no significant impact of fixed asset turnover on Jordanian services sectors' ROE. Moreover, the study concluded that the educational services sector has the lowest working capital turnover and healthcare services sector has the highest. In addition, we find that the hotels and tourism sector has the lowest total asset turnover ratio, while the utilities and energy sector has the highest and that the hotels and tourism sector has the lowest fixed asset turnover, while the utilities and energy sector has the highest. The transportation sector has the lowest ROA and technology and communication sector has the highest. Finally, we find that transportation sector has the lowest ROE and the technology and communication sector has the highest.
\end{abstract}

Keywords: working capital turnover, total asset turnover, fixed asset turnover, return on assets (ROA), return on equity (ROE), Amman Stock Exchange (ASE)

Lina Warrad, associate professor, Faculty of Economic and Administrative Science, Accounting Department, Applied Science University. Email: 1_warrad@asu.edu.jo.

Rania Al Omari, assistant professor, Faculty of Administrative and Financial Sciences, Accounting Department, Al-Asra University.

${ }^{1}$ Retrieved from http://smallbusiness.chron.com/difference-between-profitability-ratios-asset-utilization-ratios-37803.html. 


\section{Introduction}

Financial statements report on both a firm's position at a point in time and its operations over some past periods. However, the real value of financial statements lies in the fact that they can be used to help predict future earnings, dividends, and free cash flows. Profitability ratios and asset utilization ratios are considered to be the most common and simple to calculate. Each type of ratio reveals something different about a business, but they deal with some of the same measurements and issues (Schmidlin, 2014).

Working capital turnover ratio is a measure to determine how effectively a company is operating its assets to generate sales. The working capital turnover ratio is used to analyze the relationship between the money used to fund operations and the sales generated from these operations. The smaller the current capital compared to the sales in this ratio, the higher the capital turnover ratio. ${ }^{2}$ Moreover, the total asset turnover is similar to fixed asset turnover ratio, which measures a company's effectiveness in generating sales from investments related to the company. Total asset turnover evaluates the efficiency of managing all the company's assets.

The most active sector in the Jordanian economy is the service sector, which forms 67\% of the GDP. Jordan has been a participant since December 2000 in the WTO General Agreement on Trade in services and one of the seven Mediterranean partners that officially opened negotiations on liberalization on services and the right of establishment at the Euro-Mediterranean Trade Ministerial Conference in Marrakech. Liberalization will provide Jordan with an access to the EU services market, the largest in the world, and provide benefits from EU service technologies, company links, and investments. ${ }^{3}$

This paper will try to investigate the previous relations mentioned above by studying the impact of turnover ratios on the performance of the Jordanian services sectors which are listed at Amman Stock Exchange (ASE) during the period from 2009 to 2012.

\section{Previous Studies}

The impact of working capital turnover on chemical companies' profitability measured by return on assets (ROA) was presented by the study of Warrad (2014) which covered a period from 2009 to 2011, and a simple liner regression was applied. The study revealed a significant impact of independent variable working capital turnover on dependent variable ROA among chemical industries listed on ASE during the period from 2009 to 2011.

The working capital performance of Dabur India Ltd. during the period from 2003 to 2010 was investigated by Chakraborty's (2013) study which used inventory turnover ratio, working capital turnover ratio, current asset turnover ratio, and debtor's turnover ratio to achieve good performance of the company, while in terms of current ratio and the liquidity position of the company are not good.

Banks' performance was investigated by Jahan's (2012) study which used determinants of banks' profitability, which are ROA, return on equity (ROE), and return on debt (ROD) as a criterion for the Bangladesh Bank to evaluate banks' performance by evaluating the efficiency ratio, asset utilization ratio, asset size, and ROD as a determinant of banks' profitability measured by ROA. The study was conducted on randomly selected six commercial banks of Bangladesh. The results showed that the Prime Bank is considered to be superior in terms of total assets, while the Arab Bangladesh Bank is showing high performance in terms of profitability. The explanatory variables operational efficiency, asset size, and ROD were found to be

\footnotetext{
${ }^{2}$ Retrieved from http://www.finweb.com/investing/a-discussion-of-capital-turnover.html\#axzz3CMBN0wvJ.

3 Retrieved from http://www.jedco.gov.jo/joomla/index.php?option=com_content\&id=484\&Itemid=266\&lang=en.
} 
positively related and asset utilization was found to be negatively related to ROA through the results of the regression analysis, but these associations are statistically insignificant.

The impact of working capital and liquidity on the profitability of Tata Motors during the period of 2002-2010 was presented by Raheja, Bhardwaj, and Priyanka (2012) who used Karl Pearson's correlation, $T$-test, regression, rank correlation, average, and standard deviation to analyze the variables. The results revealed that there is no significant relationship between liquidity and profitability. Out of seven components of working capital, only two factors have a negative impact on profitability: working capital turnover ratio and cash turnover ratio. Also, the results showed that there was a positive correlation between working capital components and profitability.

The relationship between working capital management and profitability in firms belonging to information technology and telecommunication industry in India during the period from 1999 to 2010 was investigated by Singh's (2012) study which used pooling cross section and time series data, and 11 firms were randomly selected, out of which, five belonged to the information technology industry and six were from the telecommunication industry. The study used the return on capital employed as a measure of profitability. Other variables for working capital management were working capital turnover, current ratio, days' inventory outstanding, days' sales outstanding, days’ payable outstanding, and cash conversion cycle. The study revealed a positive relationship among working capital turnover, current ratio, sales to total asset ratio, and profitability. Days' inventory outstanding indicated a negative relationship with profitability. The relationship of current ratio with profitability was positive.

The confirmation of the existence of differences in retail firms' strategy to the direction of accomplishing profitability targets was presented by Arnis, Kolias, and Filios (2008) who used ROE and ROA ratios as well as the average sales growth rate. The results did not differ statistically within the sub-sectors of the retail sector through the previous variables. However, significant differences not only among the sub-sectors but also among firms are noticed in the other elements which define the profitability, gross margin, asset turnover ratio, and the general expenses to sales ratio. We also find, by using econometric methods, that gross margin is positively correlated with general expenses to sales ratio and negatively correlated with asset turnover ratio. The study arrives at the conclusion that the retail firms use different strategies to achieve the same ROE and ROA. Finally, the results do not support the hypothesis that the rapid developing firms show less profitability as it is expressed by ROA.

A study of Fairfield and Yohn (2001) gave the evidence that disaggregating ROA into asset turnover and profit margin does not provide incremental information for forecasting the changes in ROA one year ahead, but that disaggregating the changes in ROA into the changes in asset turnover and the changes in profit margin is useful in forecasting the changes in ROA one year ahead.

The return on investment (ROI), ROE, and probable dividend action of J. C. Penney Company, Inc. in 1978 was analyzed by Weller (1977) who concluded that return on invested capital is not projected to return to a high level within the forecast period. The company attributed the deterioration of its fixed asset turnover to the poor performance of its soft line stores.

\section{Hypotheses}

\section{Main Hypotheses}

For studying the effect of net working capital on net operating cash flow, we test the following hypotheses: 
$\mathrm{H}_{1}$ : There is no significant impact of turnover ratios on Jordanian services sectors' ROA.

$\mathrm{H}_{2}$ : There is no significant impact of turnover ratios on Jordanian services sectors' ROE.

\section{Sub Hypotheses (Branched From the Main Hypotheses)}

$\mathrm{H}_{11}$ : There is no significant impact of working capital turnover on Jordanian services sectors' ROA.

$\mathrm{H}_{12}$ : There is no significant impact of total asset turnover on Jordanian services sectors' ROA.

$\mathrm{H}_{13}$ : There is no significant impact of fixed asset turnover on Jordanian services sectors' ROA.

$\mathrm{H}_{21}$ : There is no significant impact of working capital turnover on Jordanian services sectors' ROE.

$\mathrm{H}_{22}$ : There is no significant impact of total asset turnover on Jordanian services sectors' ROE.

$\mathrm{H}_{23}$ : There is no significant impact of fixed asset turnover on Jordanian services sectors' ROE.

\section{Research Methodology}

This section presents the research methodology adopted in this study. It explains sample selection criteria, variables of the study, and research model and tests the hypotheses.

\section{The Research Sample}

The study examines the financial reports of eight Jordanian services sectors listed on the ASE for the period from 2009 to 2012.

\section{Dependent Variables of the Study}

ROA. ROA provides the readers with a measure of the profitability of a concern and the effectiveness with which the firm has used their assets. The ROA ratio may also be calculated on a pre-tax basis by using earnings before interest and tax (EBIT). Thus, the higher the ROA, the more profitable and effective the use of assets (Association of Chartered Certified Accountants [ACCA], 2008).

It can be calculated as follows (CFA, 2011):

$$
R O A=\frac{\text { Net Profit }}{\text { Average Total Assets }}
$$

ROE. ROE shows the return on capital provided by shareholders. To calculate this important ratio, net profit is set in relation to the average shareholders' equity over the business year. In the calculation, it is important to bring in net profit and shareholders' equity after minority interest has been deducted in order to only consider figures that shareholders are actually entitled to. This ratio gives investors a figure that can be compared between different firms and investment opportunities (Brigham \& Ehrhardt, 2005).

It can be calculated as follows (CFA, 2011):

$$
R O E=\frac{\text { Net Profit }}{\text { Average Shareholders' Equity }}
$$

\section{Independent Variables of the Study}

Working capital turnover. Working capital is known as current assets minus current liabilities. Working capital turnover measures how efficiently the company generates sales on its working capital. ${ }^{4}$

\footnotetext{
${ }^{4}$ Retrieved from http://www.investopedia.com/terms/w/workingcapitalturnover.asp.
} 
It can be calculated as follows (CFA, 2011):

$$
\text { Working Capital Turnover }=\frac{\text { Sales }}{\text { Average Working Capital }}
$$

Total asset turnover. Total asset turnover measures overall investment efficiency by aggregating the joint impact of both short- and long-term assets. This comprehensive measure is a key component of the disaggregation of ROA. ${ }^{5}$

It can be calculated as follows (CFA, 2011):

$$
\text { Total Asset Turnover }=\frac{\text { Sales }}{\text { Average Total Assets }}
$$

Fixed asset turnover. Fixed asset turnover measures the efficiency of long-term capital investment. The ratio reflects the level of sales generated by investments in productive capacity. The level and trend of this ratio are affected by characteristics of its components. First, sales growth is continuous, albeit at varying rates. Increase in capacity to meet that sales growth, however, is discrete, depending on the addition of new factories, warehouses, stores, and so forth. Compounding this issue is the fact that the management often has discretion over timing, form, and financial reporting of the acquisition of incremental capacity.

It can be calculated as follows (CFA, 2011):

$$
\text { Fixed Asset Turnover }=\frac{\text { Sales }}{\text { Average Fixed Assets }}
$$

\section{Research Model}

In order to test the study hypotheses, no research model can be designed, because we do not have an effectible relation.

Liner regressions. To test the research hypotheses, the Statistical Package for Social Sciences (SPSS) program was used to prepare the table of analysis of variance (ANOVA) as shown in Table 1.

$\mathrm{H}_{11}$ : There is no significant impact of working capital turnover on Jordanian services sectors' ROA.

Table 1

ANOVA ${ }^{\mathrm{a}}$ for $\mathrm{H}_{11}$

\begin{tabular}{lcclll}
\hline Model & Sum of squares & df & Mean square & $F$ & Sig. \\
\hline Regression & 73.910 & 1 & 73.910 & 2.218 & \\
Residual & 999.911 & 30 & 33.330 & & \\
Total & $1,073.821$ & 31 & & \\
\hline
\end{tabular}

Notes. ${ }^{\text {a: }}$ Dependent variable: ROA. ${ }^{\text {b: }}$ Predictors: (constant), working capital turnover.

By reviewing Table 1, we find that the $P$-value $=0.147>5 \%$, which is not significant, and this supports the acceptance of main null hypothesis. There is no significant impact of working capital turnover on Jordanian services sectors' ROA.

$\mathrm{H}_{12}$ : There is no significant impact of total asset turnover on Jordanian services sectors' ROA.

\footnotetext{
${ }^{5}$ Retrieved from http://financialanalysishub.com/total-asset-turnover/.
} 
Table 2

ANOVA for $\mathrm{H}_{12}$

\begin{tabular}{lcrlll}
\hline Model & Sum of squares & df & Mean square & $F$ & Sig. \\
\hline Regression & 15.067 & 1 & 15.067 & 0.427 & $0.518^{\mathrm{b}}$ \\
Residual & $1,058.754$ & 30 & 35.292 & & \\
Total & $1,073.821$ & 31 & & & \\
\hline
\end{tabular}

Notes. ${ }^{a}$ : Dependent variable: ROA. ${ }^{b}$ : Predictors: (constant), total asset turnover.

By reviewing Table 2, we find that the $P$-value $=0.518>5 \%$, which is not significant, and this supports the acceptance of main null hypothesis. There is no significant impact of total asset turnover on Jordanian services sectors' ROA.

$\mathrm{H}_{13}$ : There is no significant impact of fixed asset turnover on Jordanian services sectors’ ROA.

Table 3

ANOVA ${ }^{\mathrm{a}}$ for $\mathrm{H}_{13}$

\begin{tabular}{lcrcll}
\hline Model & Sum of squares & df & Mean square & $F$ & Sig. \\
\hline Regression & 0.338 & 1 & 0.338 & 0.009 & $0.923^{\mathrm{b}}$ \\
Residual & $1,073.483$ & 30 & 35.783 & & \\
Total & $1,073.821$ & 31 & & & \\
\hline
\end{tabular}

Notes. ${ }^{a}$ : Dependent variable: ROA. ${ }^{b}$ : Predictors: (constant), fixed asset turnover.

By reviewing Table 3, we find that the $P$-value $=0.923>5 \%$, which is not significant, and this supports the acceptance of main null hypothesis. There is no significant impact of fixed asset turnover on Jordanian services sectors' ROA.

$\mathrm{H}_{1}$ : There is no significant impact of turnover ratios on Jordanian services sectors' ROA.

Table 4

ANOVA $^{\mathrm{a}}$ for $\mathrm{H}_{1}$

\begin{tabular}{lcrlll}
\hline Model & Sum of squares & df & Mean square & $F$ & Sig. \\
\hline Regression & 155.683 & 3 & 51.894 & 1.583 & $0.216^{\text {b }}$ \\
Residual & 918.138 & 28 & 32.791 & & \\
Total & $1,073.821$ & 31 & & & \\
\hline Notes. a. & Dependent & & & & \\
\hline
\end{tabular}

Notes. ${ }^{a}$ : Dependent variable: ROA. ${ }^{\text {}}$ : Predictors: (constant), fixed asset turnover, total asset turnover, and working capital turnover.

By reviewing Table 4, we find that the $P$-value $=0.216>5 \%$, which is not significant, and this supports the acceptance of main null hypothesis. There is no significant impact of turnover ratios on Jordanian services sectors' ROA.

$\mathrm{H}_{21}$ : There is no significant impact of working capital turnover on Jordanian services sectors' ROE.

Table 5

ANOVA $^{\text {a }}$ for $\mathrm{H}_{21}$

\begin{tabular}{lcrcll}
\hline Model & Sum of squares & df & Mean square & $F$ & Sig. \\
\hline Regression & 62.086 & 1 & 62.086 & 0.471 & $0.498^{\mathrm{b}}$ \\
Residual & $3,950.663$ & 30 & 131.689 & & \\
Total & $4,012.749$ & 31 & & & \\
\hline
\end{tabular}

Notes. ${ }^{a}$ : Dependent variable: ROE. ${ }^{b}$ : Predictors: (constant), working capital turnover. 
By reviewing Table 5, we find that the $P$-value $=0.498>5 \%$, which is not significant, and this supports the acceptance of main null hypothesis. There is no significant impact of working capital turnover on Jordanian services sectors' ROE.

$\mathrm{H}_{22}$ : There is no significant impact of total asset turnover on Jordanian services sectors' ROE.

Table 6

ANOVA for $\mathrm{H}_{22}$

\begin{tabular}{lcrcll}
\hline Model & Sum of squares & df & Mean square & $F$ & Sig. \\
\hline Regression & 45.701 & 1 & 45.701 & 0.346 & $0.561^{\mathrm{b}}$ \\
Residual & $3,967.049$ & 30 & 132.235 & & \\
Total & $4,012.749$ & 31 & & & \\
\hline
\end{tabular}

Notes. ${ }^{a}$ : Dependent variable: ROE. ${ }^{b}$ : Predictors: (constant), total asset turnover.

By reviewing Table 6, we find that the $P$-value $=0.561>5 \%$, which is not significant, and this supports the acceptance of main null hypothesis. There is no significant impact of total asset turnover on Jordanian services sectors' ROE.

$\mathrm{H}_{23}$ : There is no significant impact of fixed asset turnover on Jordanian services sectors' ROE.

Table 7

ANOVA ${ }^{\mathrm{a}}$ for $\mathrm{H}_{23}$

\begin{tabular}{lcrlll}
\hline Model & Sum of squares & df & Mean square & $F$ & Sig. \\
\hline Regression & 266.754 & 1 & 266.754 & 2.136 & $0.154^{\mathrm{b}}$ \\
Residual & $3,745.995$ & 30 & 124.866 & & \\
Total & $4,012.749$ & 31 & & & \\
\hline
\end{tabular}

Notes. ${ }^{a}$ : Dependent variable: ROE. ${ }^{b}$ : Predictors: (constant), fixed asset turnover.

By reviewing Table 7, we find that the $P$-value $=0.154>5 \%$, which is not significant, and this supports the acceptance of main null hypothesis. There is no significant impact of fixed asset turnover on Jordanian services sectors’ ROE.

$\mathrm{H}_{2}$ : There is no significant impact of turnover ratios on Jordanian services sectors' ROE.

Table 8

ANOVA ${ }^{\mathrm{a}}$ for $\mathrm{H}_{2}$

\begin{tabular}{lcrlll}
\hline Model & Sum of squares & df & Mean square & $F$ & Sig. \\
\hline Regression & 856.000 & 3 & 285.333 & 2.531 & $0.077^{\mathrm{b}}$ \\
Residual & $3,156.749$ & 28 & 112.741 & & \\
Total & $4,012.749$ & 31 & & & \\
\hline
\end{tabular}

Notes. ${ }^{\text {a }}$ : Dependent variable: ROE. ${ }^{\text {b: }}$ Predictors: (constant), fixed asset turnover, total asset turnover, and working capital turnover.

By reviewing Table 8, we find that the $P$-value $=0.077>5 \%$, which is not significant, and this supports the acceptance of main null hypothesis. There is no significant impact of turnover ratios on Jordanian services sectors' ROE.

\section{Statistical Analysis}

This section presents the results of descriptive statistics for the study variables. 
Table 9

Independent Variables Ranking Among Jordanian Services Sectors

\begin{tabular}{llcllll}
\hline Sector & Rank & $\begin{array}{l}\text { Working capital } \\
\text { turnover }\end{array}$ & Rank & $\begin{array}{l}\text { Total asset } \\
\text { turnover }\end{array}$ & Rank & $\begin{array}{l}\text { Fixed asset } \\
\text { turnover }\end{array}$ \\
\hline Healthcare services & 7 & 22.72691032 & 2 & 0.437600028 & 3 & 0.820361 \\
Educational services & 1 & -341.5877909 & 3 & 0.485854432 & 2 & 0.725536 \\
Hotels and tourism sector & 2 & -18.70213213 & 1 & 0.217584706 & 1 & 0.347901 \\
Transportation sector & 3 & -9.023490437 & 7 & 1.232560347 & 6 & 2.336932 \\
Technology and communication & 4 & 3.348739266 & 5 & 0.638342112 & 5 & 2.108911 \\
Media sector & 6 & 8.266755908 & 4 & 0.615516328 & 4 & 1.394416 \\
Utilities and energy & 8 & 67.72690163 & 8 & 1.915349438 & 8 & 8.719408 \\
Commercial services & 5 & 6.2270192 & 6 & 0.818082456 & 7 & 2.373262 \\
\hline
\end{tabular}

By reviewing Table 9, we found that the educational services sector has the lowest working capital turnover and utilities and energy sector has the highest. In addition, we find that the hotels and tourism sector has the lowest total asset turnover ratio and the utilities and energy sector has the highest. We also find that the hotels and tourism sector has the lowest fixed asset turnover and the utilities and energy sector has the highest.

Table 10

Dependent Variables Ranking Among Jordanian Services Sectors

\begin{tabular}{llclc}
\hline Sector & Rank & ROA & Rank & ROE \\
\hline Healthcare services & 4 & 2.45221 & 4 & 2.40506 \\
Educational services & 7 & 12.34124 & 7 & 16.08534 \\
Hotels and tourism sector & 3 & 2.347837 & 3 & 1.505846 \\
Transportation sector & 1 & 0.498605 & 1 & -3.49581 \\
Technology and communication & 8 & 13.06871 & 8 & 21.74977 \\
Media sector & 2 & 2.167077 & 2 & 1.382623 \\
Utilities and energy & 6 & 4.083593 & 6 & 14.03826 \\
Commercial services & 5 & 3.065356 & 5 & 2.792097 \\
\hline
\end{tabular}

By reviewing Table 10, we found that the transportation sector has the lowest ROA and the technology and communication sector has the highest. We also find that the transportation sector has the lowest ROE and the technology and communication sector has the highest.

\section{Summary and Conclusion}

This study aims to approve if there is a significant impact of turnover ratios expressed by working capital turnover, total asset turnover, and fixed asset turnover on Jordanian services sectors' performance expressed by ROA and ROE.

The results showed that there is no significant impact of turnover ratios on Jordanian services sectors' profitability, and by testing the main and sub hypotheses, the study revealed that there is no significant impact of turnover ratios on Jordanian services sectors' ROA, there is no significant impact of working capital turnover on Jordanian services sectors' ROA, there is no significant impact of total asset turnover on Jordanian services sectors' ROA, and there is no significant impact of fixed asset turnover on Jordanian services sectors’ ROA. 
Also, the study results showed that there is no significant impact of turnover ratios on Jordanian services sectors' ROE, there is no significant impact of working capital turnover on Jordanian services sectors' ROE, there is no significant impact of total asset turnover on Jordanian services sectors' ROE, and there is no significant impact of fixed asset turnover on Jordanian services sectors’ ROE.

Moreover, the study concluded that the educational service sector has the lowest working capital turnover and the utilities and energy sector has the highest. We also find that the hotels and tourism sector has the lowest total asset turnover ratio and the utilities and energy sector has the highest and the hotels and tourism sector has the lowest fixed assets turnover while the utilities and energy sector has the highest. The transportation sector has the lowest ROA and the technology and communication sector has the highest. In addition, we find that the transportation sector has the lowest ROE and the technology and communication sector has the highest.

The findings of this study differ from studies investigating the same relations, and its results disagree with the results of most previous studies which found a significant effect of turnover ratios on profitability. This is what distinguishes this study from others, which can be explained by the distinct item between the sales as a numerator of the turnover ratios and the net income as a numerator of ROA and ROE which is cost of sales.

In order to maintain a significant effect of turnovers on profitability, the cost of sales should move in parallel with sales movements positively at the same percent or less.

This study mentioned that in order to intervene in market competition, the services sectors should follow the net profit deduction strategy, and the way to achieve that was to increase the cost of sales with a higher percent than the increase in sales. This revealed a distortion in the expected relationship between turnover ratios and profitability ratios, because of which, the study found no significant impact of turnover ratios on Jordanian services sectors' profitability.

We will apply the study among Jordanian services sectors as a comparative study, in order to investigate different conclusions among different sectors within ASE sectors.

\section{References}

Arnis, N. I., Kolias, G. D., \& Filios, V. F. (2008). The profitability of the Greek retail firms and the relations among the determinants (in Greek). Review of Economic Sciences, 14, 161-180.

Association of Chartered Certified Accountants [ACCA]. (2008). Paper F7, financial reporting (International).

Brigham, E. F., \& Ehrhardt, M. C. (2005). Financial management, theory, and practice (11th ed.). Mason, OH: Thomson Southwest.

CFA. (2011). Financial reporting and analysis. Program Curriculum, Volume 3, Level 1.

Chakraborty, N. (2013). Working capital performance: A case study on Dabur India Ltd.. International Journal of Research in Commerce and Management, 4(10), 93-97.

Fairfield, P. M., \& Yohn, T. L. (2001). Using asset turnover and profit margin to forecast changes in profitability. Review of Accounting Studies, 6(4), 371-385.

Jahan, N. (2012). Determinants of bank’s profitability: Evidence from Bangladesh. Indian Journal of Finance, 6(2), 32-38.

Raheja, R., Bhardwaj, R., \& Priyanka. (2012). The impact of working capital management on profitability and liquidity. International Journal of Research in Commerce and Management, 3(3), 99-102.

Schmidlin, N. (2014). The art of company valuation and financial statement analysis: A value investor's guide with real-life case studies. John Wiley \& Sons.

Singh, D. P. (2012). Working capital management and profitability in the IT and telecom industry in India. Indian Journal of Finance, 6(3), 54-61.

Warrad, L. (2014). The impact of working capital turnover on Jordanian chemical industries' profitability. American Journal of Economics and Business Administration, 5(3), 116-119.

Weller, E. A. (1977). Return on investment, return on equity, and probable dividend action (pp. 8-9). J.C. Penney Company. 